\title{
Development of Student Ecological Intelligence Through the Implementation of Ecopedagogy
}

\author{
Akhmad Fauzi $^{1 *}$, Susan Fitriasari ${ }^{2}$, Dwi Iman Muthaqin ${ }^{3}$ \\ ${ }^{1,2,3}$ Universitas Pendidikan Indonesia \\ 'Corresponding author. Email: akhmadfauzi.ozi@student.upi.edu
}

\begin{abstract}
The issue of environmental damage is a serious problem that must be resolved immediately and must be considered from a small scope but has a large influence, as in the field of education can be applied through the implementation of the ecopedagogy to develop students' ecological intelligence. This study aims to determine how effective Ecopedagogy in developing ecological intelligence students in the learning process in the class. This research approach with a mixed approach (mix method), a method in this research using the method of class action research (Classroom Action Research). This research was conducted on students of Class X MIPA 5 SMA Negeri 14 Bandung as research subjects, the application of ecopedagogy was conducted in 3 cycles. The results showed that the application of Ecopedagoy could develop students' ecological intelligence. This can be seen from the change of student behavior, which at first the majority always disposed of littering, using sterofoam, disposable bottles and plastics, in other words having a low ecological intelligence and awareness of participating in preserving low environmental sustainability by not adhering to school rules especially in terms of preserving the environment of the school, being enthusiastic about taking civics lessons.-based learning model of green constitution also makes students sensitive to various environmental issues and problems and then be able to position themselves either as students or as citizens of Indonesia.
\end{abstract}

\section{Keywords: Ecopedagogy, Ecological Intelligence, Civic Education}

\section{INTRODUCTION}

Humans and the environment areone unit in forming an ecosystem and depends on the environment surroundings, be it the natural environment (physical) and social environment. Urgency of effort preserving the natural environment is the responsibility of the world community as earth dwellers and resource users natural. argued that the ecological crisis is a vital problem facing all man. Therefore, education very important for development environmental awareness and for strengthen individual abilities and community in the fight against actions that can lead to an environmental crisis [1].

Human activities in order fulfillment of the necessities of life in all aspects have a significant impact to the environment, an accurate analysis of the environment must always consider the total impact of man and his culture on all the surrounding elements, and also the impact of ecological factors on every aspect of human life. Viewed in this perspective the environment includes biological, physiological, economic and cultural aspects, all linked in the same constantly changing ecological fabric. As a global ecosystem, the earth was formed and is influenced by systems that smaller including the human perspective individually in understanding the place where he lives. In man, perception of place and space is processed through thinking skills and manifested in behavior towards the surrounding environment which is one inseparable unity, that one development citizenship is treating earth as part of their life together in harmony [2].

Education has a role fundamental in building character students to always have sensitivity and concern for the natural environment around. students need to be prepared to be able to respond to various crises ecologically by forming attitudes and caring as a form of responsibility human responsibility for the future together and sustainable living [3].

In fact, cultivate attitude care for the environment has not been fully maximally realized. Student yet have an attitude of caring for the environment as expected [4]. indicated in some ways is still a lot of environment dirty school, student participation in environmental activities are still low, there is no student awareness in shape environmental behavior, behavior wasteful in the use of resources nature, apathy towards the preservation of the 
environment around students. environmental attitude includes a person's behavioral goals, impact, and the trust gained of environmental subjects or activities as well as it is stated that environmental attitudes can used to predict behavior to the environment [5].

\section{THEORETICAL REVIEW}

Ecopedagogy can be defined as: academic movement to make students aware students become individuals who have understanding, awareness and life skills in harmony with nature conservation interests [6]. The environment is a means for someone who believes in the value that then shape his attitude. our ability to adapt to the ecological niche of the place we are called intelligence ecological. A person's attitude will be seen when he responds to the surrounding environment in accordance with the values which he adheres to, in this case it's good natural environment and social environment [7]. Ecopedagogy can also be used as a approach to learning that make students as independent learning, autonomous, able to develop their learning potential based on the experience brought from outside the classroom and realize that every his actions will have an impact on himself and environment [8].

Ecopedagogy or ecopedagogy is not a teaching method, isn't it also as the best method in environmental education. Even On the other hand, the ecopedagogical movement against environmental education practices life that emphasizes the importance moment, that separates humans from environment, which is not oriented towards future, and does not support the concept continuity [9]. ecopedagogical goals Among them are, 1) to help explain concerns and concern about the interdependence between economic, social, political, and ecological aspects both in cities and in rural areas, 2) to give opportunity to everyone in developing knowledge, values, attitudes, commitment, and the skills needed to protect and improve the environment, 3) to create patterns of behavior that new to individuals, groups, and society as a whole to the environment. Desired goal achieved includes aspects of knowledge, attitude, care, skills and participation [10].

Based on the above, it can be It is understood that the aim of ecopedagogy is build collective awareness for play an active role in maintaining and caring for planet earth, because nature is space giver and meaning of life, and not only as a living environment (environment) only. On the other hand, ecopedagogy is education that can change the paradigm of science that only understood as something that mechanistic, reductionist, partial and value-free to be ecological, holistic and bound by values so that wisdom can grow (wisdom). Besides, ecopedagogy too is education to recognize nature, so that love grows (respect) towards nature [11].
Ecopedagogy is a movement thinking as part of pedagogy critical pedagogy in education from the thinkers of the Frankfurt School at Germany with its character Jurgen Habermas, Paulo Fraire (Latin America), Henry Giroux and Richard Kahn (United States). Things that come to mind This includes criticizing the implementation of modern education that departs from positivistic tradition that makes humans as a medium of production for increase power in various field so that it has an effect against increasing exploitation natural resources. to return human in the essence of humanity as a human who lives in harmony with nature according to the concept of sustainability which is integrated in education. Sustainability concept to prepare participants students have a far-sighted perspective about the importance of independence (autonomy), justice, and live better in harmony with nature.

Ecopedagogy-oriented ecological awareness in multiple perspectives as an effort to build wisdom over the dimensions of life people. In more reviews comprehensive. The fundamentals of the eco- pedagogy include protection of nature (natural ecology), the impact of the human societies upon nature (social ecology) as well as the influence over civilization and economic, social and cultural composition (integrated ecology) therefore, essentially it promotes respect for nature, human, culture and diversity [12].

\section{METHODS}

The design used in This research is a qualitative approach with the classroom action research method (classroom action research) in particular emancipatory action research. Based on participatory action philosophical view research (PAR) namely self emancipation, self reflection, and self awareness, own teaching practices more human and justice and collaborative effort [13]. then this research developed through a process of dialogue and collaborative interview between researchers with class teachers and research subjects grade X students with a total of 124 students. Data collection technique using triangulation, namely the researcher using data collection techniques different to get data from the same source in the same way participatory observation, interview depth and documentation [14].

Variables in this study focused on observing caring attitude student environment and skills contribute to the preservation of the environment, such as 1) throwing skills trash in its place, 2) sorting organic and inorganic waste, 3) participate play a role in caring for the school garden, 4) reduce consumption goods plastic packaging, and 5) not doing actions that can undermine conservation environment like not uprooting plants and do not commit vandalism. 


\section{RESULTS AND DISCUSSION}

Based on the results of participatory observations, indepth interviews and documentation, participants students show increased understanding them about environmental issues, show caring behavior cleanliness of the school environment and can show concern for protect themselves and the environment in which they live is at ecopedagogy views environmental education from a different perspective holistic view of human nature as part of from nature. Skills in throw garbage in its place, sort out organic and inorganic waste, watering plants, recycle paper waste and plastic, can already describe the part small from the attitude of caring for the environment done by students, if nature can perceived as a place for the individual, then it would be very possible for individuals to care and committed to nature conservation [15].

Dialogues and interviews were conducted between researchers with research subjects (students) and teachers about environmental issues faced in everyday life and the importance have a caring attitude towards the environment. Issue environment and student attitudes in elementary school studied are as follows. First, students who go to and return to school with using fossil fueled vehicles. Congested city traffic situation with high levels of air pollution. They too often see piles of garbage on the banks of the the side of the road and in the neighborhood around the school discarded by the local community. Condition like that can be more or less threatening their health, then they have felt and witnessed reality the poor environment of the city around them. Experience from this can be part of civic education learning materials. Second, students realize that the physical environment green and clean is a place that convenient for them. On the other hand, the students will feel that the environment is dirty and Pollution is one of the threats to their health both now and future. school place research has a fairly large garden but not many types of plants are is there and the land has not been used maximally for green open space in school environment. Should be in every school has green open space as a means of minimizing air pollution that occurs and as a participatory tool for students in developing a caring attitude environment.

To develop a caring attitude environment for students, teachers take some steps in classroom action research as follows. First, have a dialogue with participants such as principals, teachers, and students, so that all concerned parties are aware of the problem environment. For example, head school as the holder of authority policies at the school can create a program with a green theme behavior or can also take advantage of school garden to the maximum through "Teras Sekolah" program. Teacher in draw up a lesson plan must be glued to the curriculum document who are less adopting the issue and students' experience. Learning civic education about the environment can be more meaningful for students if the material learning is lifted from experience students and not only from textbook. Second, take action direct (practice) in good learning inside and outside the classroom. Key principles and components of green behavior be an aspect to be studied and practiced in civic education learning. The second step is accompanied by the third step is observation for see the success of planting attitude environmental care. Research ends with reflection done by all participant.

From the effective aspect, it will form students' understanding in be ecological in civic education learning with approach ecopedagogy in particular, generally on implementation of daily behavior. attitude towards the environment covers several aspects, including: 1) appreciation and concern for environment, 2) response and thought to environmental issues, 3 ) respect people's opinions and views others to the environment, 4) appreciate the evidence and arguments logical towards environmental management life, and 5) tolerance and openness in various problems and management of the environment [16].

The visit was carried out by students to the traditional market located in near the school, it aims to develop competence in choose healthy foods. Activity the other is to train them use one shopping bag environmentally friendly and to avoid use of plastic bags in shop. Another important thing that can be applied is to familiarize students to bring food from home and bring a refillable water bottle, thereby reducing plastic consumption and reduce the amount of plastic waste in school. To reduce use paper in civic education learning, students asked to use two sides of paper in writing, because of student habits in writing only on one page can increase paper consumption. In fact, activities reduce the use of paper in one school is not will have a direct impact on prevention deforestation in Indonesia. However, if it's done by everyone then forests as the lungs of the earth can continue preserved. The next activity is by doing the $4 \mathrm{Rs}$ (reduce, reuse, recycle, and replace), which is to collect used and recycled paper revert to a new thing that can be used as learning media like an embossed map. This activity is not only reduces paper waste however also helps reduce pollution generated by waste. Engaging students interact directly with activities environmental preservation has implicitly build an attitude of responsibility. provide opportunities for children to be close to nature and spending time outdoors can indicate predictors of child behavior responsible for environment.

\section{CONCLUSION}

learning by approach ecopedagogy in instilling attitudes caring for the environment is one efforts to prepare the next generation will come as a generation that has concern for the environment. Ecopedagogy-based learning oriented to the achievement of understanding completely about human nature and nature that has an essential relationship, so this has implications for growing critical awareness and formation of student attitudes. Based on the 
results of observations and interviews, students show improvement their understanding of the problem environment, showing behavior who care about environmental cleanliness where they are. Behavior in Throw garbage in its place, sorting organic and inorganic waste, watering plants, using two sheets of paper, recycling trash paper and plastics, as well as reducing consumption of unfriendly products environment describes competence environmental care attitude invested in this study. Study this is a small step in social studies learning in elementary school prepare students as citizens people who care about issues local and global environment. Results this research will not solve environmental problems such as global warming, changing seasons, depletion of natural resources, effects greenhouse, loss of various kinds living things, and so on in short time. However, to support better continuity of life on the surface of the earth, small steps in packaged environmental education in learning including learning civic education. Starting in the school environment, participants students can be provided with steps simple steps in living eco-friendly life since early childhood, namely in the school environment, at home, and community environment.

\section{AUTHORS CONTRIBUTION}

Susan Fitriasari and Akhmad Fauzi conceived of the presented idea. All authors discussed the results and contributed to the final manuscript

\section{ACKNOWLEDGMENTS}

This research is a grant from Universitas Pendidikan Indonesia, The authors would like to express sincere appreciation for all support provided.

\section{REFERENCES}

[1] Eryaman, M. Y., Yalçın Özdilek, Ş., Okur,E., Çetinkaya, Z., \& Uygun, S. 2010.“A Participatory Action ResearchStudy of Nature Education in Nature:Towards Community-based Ecopedagogy". International Journal of Progressive Education, vol.6, 3, 26-37

[2] Ward, B \& Dubos, R. 1973. The UNESCO Courier (Only One Earth). London: Penguin (Paperback).

[3] Tsegay, S.M. 2016. "Analysis of Globalization, the Planet and Education". International Journal of Environmental \& Science Education, vol.11, 18, pp. 11979-11991.

[4] Sapriya. (2011). Pendidikan IPS. Bandung: Remaja Rosdakarya.

[5] Muhaimin. 2015. Membangun Kecerdasan Ekologis. Bandung: Alfabeta

[6] Okur, E, \& Berberoglu. 2015. "The Effect of Ecopodagogy-Based Environmental Education on Environmental Attitude of Inservice Teachers".
International Electronic Journal of Environmental Education, vol.5, 2, 86-110.

[7] Kahn, R. 2010. Critical Pedagogy, Ecoliteracy and Planetary Crisis. New York: Peter Lan.

[8] Goleman, D. 2010. Ecological Intelligence: How Knowing The Hidden Impacts Of What We Buy CCn Change Everything (Edisi Bahasa Indonesia). Jakarta: Gramedia Pustaka Utama

[9] Gadotti, M. 2010. "Reorienting Education Practice Towards Sustainability". Journal of Education for Sustainability, vol. 4, 203.

[10] Supriatna, N. 2016. Ecopedagogy Membangun Kecerdasan Ekologis dalam Pembelajaran IPS. Bandung: Rosdakarya

[11] Muhaimin. 2015. Membangun Kecerdasan Ekologis. Bandung: Alfabeta.

[12] Yunansah, H, \& Herlambang, Y. 2017. "Pendidikan Berbasis Ekopedagogik dalam Menumbuhkan Kesadaran Ekologis dan Mengembangkan Karakter Siswa Sekolah Dasar”. Jurnal Pendidikan Dasar, vol.9, 1, 27-34.

[13] Gadotti, M. 2008. "What We Need to Learn to Save the Planet". Journal of Education for Sustainable Development, vol.2, 1, 21-30.

[14] Carr, W and Kemmis, S. 1996. Becoming Critical, Education, Knowledge and Action Research. Melbourne: Deakin University Press

[15]Hung, R. 2014. "In Search of Ecopedagogy: Emplacing Nature in the Light of Proust and Thoreau". Journal Educational Philosophy and Theory, vol.46, 13, 1387-1401, doi: 10.1080/00131857.2014.914874

[16] Lauren E. Mullenbach, Rob G. Andrejewski \& Andrew J. Mowen. 2018. Connecting Children to Nature through Residential Outdoor Environmental Education". Environmental Education Research, doi: 10.1080/13504622.201 8.1458215 . 